\title{
The Influence of Motivational Conflicts on Personal Values
}

\author{
Britta Kilian \\ Competence Center for the Advancement of Academically Gifted Students \\ Universitätspark 21, D-73525 Schwäbisch Gmün, Germany \\ E-mail: britta.kilian@gmx.de \\ Manfred Hofer (Corresponding author) \\ University of Mannheim \\ Neckargrün 6, D-68259 Mannheim, Germany \\ Tel: 49-621-795-364Ｅ-mail: manfred.hofer@sowi.uni-mannheim.de
}

Claudia Kuhnle

Fröbelstr. 12, D-70794 Bernhausen, Germany

E-mail: claudineoz@web.de

$\begin{array}{lcc}\text { Received: January 17, } 2012 & \text { Accepted: April 6, } 2012 & \text { Published: May 1, } 2012 \\ \text { doi:10.5539/jedp.v2n1p57 } & \text { URL: http://dx.doi.org/10.5539/jedp.v2n1p57 }\end{array}$

The research is financed by the German Research Foundation, research grant HO 649/19-1.

\begin{abstract}
In an experimental study with university students, the authors tested the assumption that the importance students place on achievement, conformity, well-being, and hedonistic values depend on their perceptions of their reactions in conflicts between school and leisure activities. In a $2 \times 2$ design, the authors manipulated both the extent to which students' self-regulation during an achievement-related task (Bourdon-Test) is impaired based on a leisure-related temptation (read and rate jokes) as well as the extent to which students' attention is directed toward these reactions. Results indicated an effect of the experimental manipulation on participants' achievement values. The authors discuss the results in terms of a potential reciprocal direction of influence between experiences in motivational action conflicts and the personal values associated with those actions.
\end{abstract}

Keywords: Motivation, School-leisure, Conflict, Personal values, Value change

\section{Introduction}

Imagine the following scenario: It is early evening and a student is sitting at a desk, working on homework. This student knows that the teacher might collect the homework the next day and grade it. School is important to this student, and therefore achieving a good grade is also important. At the same time, a new episode of the student's favorite TV show is on. This student would rather be watching the show at this time, but instead tries to stick to the homework because there is not much time to finish it. The student keeps working and tries to forget about the TV show, but it is difficult for the student to put the TV show out of mind. This student cannot concentrate on the homework for thoughts of the show, and finally ends up turning the TV on and off, which interrupts the homework assignment again and again. After a while, this student realizes what is happening and thinks, "Maybe school is not so important to me after all."

Students are frequently torn between studying for exams and going out with friends, between finishing papers and watching TV, or between working on assignments during class and writing notes with friends or texting on cell phones. Usually, researchers face the question of whether students' personal values affect the choice of an alternative, the performance of the chosen option, and the result of the performance. In fact, studies suggest that 
students' values affect their decision for an alternative in such conflicts and the experiences during the performance of the chosen activity (Fries, Schmid, Dietz, \& Hofer, 2005; Hofer et al., 2007). However, the reverse direction of influence is also possible. Longitudinal studies pointed toward a reciprocal influence over time between values and experiences during study-leisure conflicts (Hofer, Schmid, Fries, Kilian, \& Kuhnle, 2010; Kilian, Hofer, \& Kuhnle, 2010). In the present paper, values are conceptualized as consequences of motivational processes. There is reason to assume that if persons direct their attention toward their own reactions in conflicting situations, the values they hold can change based on conflict experiences.

\subsection{Values and Value Change}

Rokeach (1973) defined personal values as beliefs where specific modes of conduct are preferable to an opposite mode of conduct. Values are more abstract than goals and can be used as criteria to evaluate goals (Fries, Schmid, $\&$ Hofer, 2007). Concerning value content, Inglehart (1997) distinguished between modern values, such as hard work, security, and prosperity, and postmodern values, such as leisure, friends, self-actualization, and tolerance. He argued that from the 1960s onward, postmodern values have become increasingly important in Western societies, and that more and more so, modern and postmodern values coexist (Inglehart \& Welzel, 2005). Independently, Schwartz (e.g., Schwartz, 1996; Schwartz et al., 2001) specified a comprehensive set of 10 value constructs; for example, power, hedonism, stimulation, universalism, tradition, and conformity. The relations between these values are best described in a circular structure: The closer any two values are to one another in the circle, the more compatible they are. Conversely, the more distant they are, the more they are in conflict.

Values are seen as guiding principles in people's lives (Bardi \& Schwartz, 2003). They are relatively enduring, but can and do undergo changes over time (Grube, Mayton, \& Ball-Rokeach, 1994; Hofmann-Towfigh, 2007; Sheldon, 2005), or with dramatic events (Verkasalo, Goodwin, \& Bezmenova, 2006). Also, experimentally induced manipulations can lead to substantial, and in part, long-lasting value changes (Bernard, Maio, \& Olson, 2003; Rokeach, 1975; Rokeach, 2003; Rokeach \& Cochrane, 1972). According to Rokeach (1973), value change is a rearranging of value priorities. Concerning its underlying process, value change has been conceptualized as an answer to the question "What must I value if I am trying to attain certain goals, and thereby act, feel, and think in certain ways?" (Hofer, Reinders, \& Fries, 2010). This idea follows Bem's (1967) postulation that individuals can come to know their internal states (such as attributes, attitudes, and values) by inferring them from observations of their own behavior and the circumstances in which the behavior occurs. If internal cues are weak, ambiguous, or uninterpretable, individuals are in the same position, functionally, as outside observers. As a result, they infer their internal states from their behavior in such a way that the behavior cannot be explained by external controlling forces, for example, as payments or punishments (e.g., Bem, 1967, 1972). While Bem followed a behaviorist tradition and focused on external behavior as clues, more recent work has emphasized that people base their self-perception not only on overt actions, but also on their cognitions (Damrad-Frye \& Laird, 1989; Dolinski, 2000). People constantly monitor their cognitions and feelings (Koriat \& Levy-Sadot, 1999) and use them in processes of self-definition as well (Robak, Ward, \& Ostolaza, 2006).

Following this line, we argue that individuals can observe their behavior, feelings, and internal reactions in conflict situations between actions that are associated with different values. Based on these observations, individuals can infer how much importance they place on those values. Which kind of inner state are students supposed to focus on? Think back to the student who has to do homework for the next day while a favorite show is on TV. While trying to do homework despite the TV temptation, this student might be in a bad mood, have poor concentration, and consequently experience weakened persistence with the homework, or even switch back and forth between TV and homework. This inner state is denoted as experience of motivational interference. The incentives that stem from an attractive alternative that is not chosen impair the performance of the chosen action (Fries, Dietz, \& Schmid, 2008). If the student experiences high motivational interference while trying to work on the homework assignment, then this student could infer that the values he attaches to studying are not highly important to this student. Likewise, the student also infers that a lot of internal emphasis is being placed on values having to do with enjoying something because this student is drawn so much to the TV. If, on the other hand, the student's internal observation is as one who concentrates on homework and is not distracted by the TV, this student might infer that, internally, a lot of importance is placed on work values and not so much on enjoyment. Thus, on the one hand, we expect inferences to be drawn to the values associated with the main task, and on the other hand, to values associated with the alternative task. The reported experiment consisted of a performance task that allowed for shifting to a more pleasurable activity. Here, two groups of students worked on the same task, which differed in the degree of interestingness. As a consequence, on the basis of previous research results, they should differ in the degree of motivational interference stemming from the incentives of the attractive alternative. 
As individuals vary in their general tendency to direct attention inwardly (Fenigstein, Scheier, \& Buss, 1975) and certain situations foster self-reflections more than others (Duval \& Wicklund, 1972), the extent to which students change their values based on conflict experiences should depend on how much they reflect upon their reactions in conflict situations. If the student who is in a bad mood and cannot concentrate while trying to work on homework instead directs attention inwardly toward these reactions, then the student should develop little regard for work values, but high regard for leisure-related values. If, conversely, the student's attention is not directed toward these experiences, an influence on values is unlikely. Thus, the extent to which students focus their attention on the self and perceive their own experiences in conflict situations should moderate the expected relationship between conflict experience and values: Only when self-focus is high should conflict experience influence values. The experiment included two groups differing in the amount of self-focus.

\subsection{Values in Study-leisure Conflicts}

In each individual's value system, values are ordered in priority or importance relative to one another (Schwartz, 2006). It has been argued that personal values play little role in people's lives except in conflict situations when a behavior has consequences which are promotive of one value but opposed to another (Schwartz, 1996). Therefore, values should be especially applicable to conflict situations in which students have to decide between different action alternatives that offer incentives to different values. As a typical conflict situation, we simulated a school-leisure conflict. It is increasingly acknowledged that high school and university students face conflicts between school and leisure activities rather frequently (Fries et al., 2005; Ratelle, Vallerand, Senécal, \& Provencher, 2005). School activities primarily, though not exclusively, offer incentives for work-related values, while leisure activities are more connected to pleasure-related values.

In this study we included two sets of values. Following Inglehart (1997), achievement and well-being values were conceptualized in a manner that incorporates those value aspects that turned out to be important to student life in an interview study (Schmid, Hofer, Dietz, Reinders, \& Fries, 2005). Achievement value describes the amount that students value success, clear goals, and hard work, while well-being value describes the amount that students value fun, leisure, and spontaneous activities. In addition, from the Schwartz' values, conformity - the restraining of actions, inclinations, and impulses that could violate social expectations or norms (Schwartz et al., 2001) - should mainly be in accordance with the school alternative, while hedonism - the importance of pleasure and sensuous gratification for oneself (Schwartz et al., 2001) - should primarily be in line with the leisure alternative. The two values lie at opposite poles of the value circle and are likely to come into conflict (Schwartz, 1992). Although in the Schwartz conceptualization there is also a value called achievement, this is hardly applicable to school-leisure conflicts because achievement there is defined as the importance of personal success through demonstrating competence compared to others (Schwartz et al., 2001).

\subsection{Hypotheses}

Students had to perform a school-type activity in the face of a leisure temptation. According to the values attached to the main activity and to the alternative, the two expectations were the following:

1) In the high self-focus condition, students in the group in which high motivational interference was created perceive themselves as being less orientated toward achievement and conformity values compared to students in the condition with low motivational interference.

2) In the high self-focus condition, students in the group in which high motivational interference was created perceive themselves as being more orientated toward values of well-being and hedonism compared to students in the condition with low motivational interference.

\section{Method}

\subsection{Sample}

A total of 89 university students participated in the experiment. Participants were recruited on campus by direct approach or by using recruitment flyers. Nine participants had to be excluded from the analyses because they did not follow the instructions properly (e.g., completed everything in an implausibly short time) or because of language difficulties. On average, the remaining participants were 21.63 years old $(S D=2.38)$, and $74.7 \%$ were female. The majority of the participants were in the second $(62 \%)$ or fourth $(24.1 \%)$ semester, with smaller numbers of participants also in the first, fifth, and sixth semester. Participants studied different subjects, such as psychology, economics, business administration, law, and sociology.

\subsection{Tasks}

Following experiments that created the situation of a school-leisure conflict in the lab (Fries \& Dietz, 2007), 
students had to complete an achievement-related main task while an attractive alternative task was offered. As the main task, students had to work on a concentration task that was developed based on material from the Bourdon-Tests (see, e.g., Dietz, 2006). Participants were given a sheet with a $25 \times 30$ matrix of symbols. Additionally, they were given a list with 24 different symbols that they had to consecutively search and mark on the sheet - thereby counting how often they occurred - and had to write this number down. Each of the 24 symbols appeared in the matrix between one and nine times. An example of the performance task is given in Figure 1. The task was chosen because personality factors, such as previous knowledge or interest, do not play a role. Although it might seem less meaningful than the average student task, it is similar to most student tasks in that it requires concentrated and dedicated work. The number of symbols was determined in pretests so that it would be nearly impossible to complete all of them in the allotted time. All students were given the opportunity to be distracted by having access to an alternative task; namely, to read and rate jokes on nine-point rating scales from very funny to not funny at all. The alternative task was chosen as a task that is more fun than the main task. According to previous research results, it is expected that the sheer presence of the option produces motivational interference in students regardless of whether they choose to follow the distraction or not.

\section{Insert Figure 1 Here}

\subsection{Experimental Conditions}

The design of the experiment was a $2 \times 2$ design in which the extent that students experience motivational interference as well as the extent that students directed their attention toward these reactions were manipulated. In order to manipulate the extent of motivational interference that students experience while working on the main task when the alternative task is present, the intrinsic motivation for the main task was manipulated by employing it with a fantasy context for half of the participants. Fantasy contexts increase intrinsic motivation (Cordova \& Lepper 1996; Parker \& Lepper, 1992; Wang \& Reeves, 2007). Similar to Parker and Lepper (1992), for participants in the fantasy context condition, the task of searching for the symbols was embedded in the story of being an astronaut who has to find the symbols to complete a space mission. For the no fantasy context condition, no such story was provided. The space frame was chosen because it was seen as distant enough from everyday student life so as to not prime achievement or well-being values. Framing an unattractive main task in a fantasy context when an attractive alternative task is present significantly decreased motivational interference of college students compared to when no framing was provided (Dietz, 2006). Regulating the experience of interest for an activity through the use of different strategies can be a powerful tool for maintaining activities that were originally not very interesting (e.g., Sansone \& Thoman, 2005).

In order to manipulate the extent to which students directed their attention toward their own reactions to the conflict situation, participants in the high self-focus condition answered items about their current experience of motivational interference in between searching for the symbols. Six items from Fries and Dietz (2007) were used and adapted to the situation of the experiment where necessary. An example is "While I am searching for the symbols, I am distracted by the idea of rating jokes" rated with a five-point rating scales from not true (1) to very true (5). Participants in the low self-focus condition answered unrelated items about grocery stores at the same time.

\subsection{Dependent Variables}

\subsubsection{Well-being and Achievement Value Orientation}

Values were assessed using similarity ratings. This method of assessing values is seen as easier for the participants than abstract importance ratings (Schwartz et al., 2001). Well-being value orientation was measured by six items that consisted of statements about six different students (e.g., "According to student D. U., life should only consist of free time"). Achievement value orientation was assessed by five items consisting of five statements about students (e.g., "For student T. A., it is mainly important to achieve something in life"). The items were developed based on comprehensive descriptions of students representing prototypes with regard to their value orientation (Fries et al., 2005). For each student description, participants rated how similar the student is to them on a six-point rating scale ranging from very similar (6) to very dissimilar (1).

\subsubsection{Schwartz Scales}

To assess the values derived from Schwartz, his Portrait Values Questionnaire (Schwartz et al., 2001) was used. All 40 items assessing the ten values were administered. Only eight of the items (the scales for conformity and hedonism) were relevant to the hypotheses. The items presented short descriptions of people, and the participants had to rate items about how similar the people being described were to them on six-point rating scales ranging from very similar (6) to very dissimilar (1). Conformity was measured with five items (e.g., "He believes that 
people should do what they're told. He thinks people should follow rules at all times, even when no one is watching"). Hedonism was measured with three items (e.g., "He really wants to enjoy life. Having a good time is very important to him"). All value items were presented in gender congruent versions.

\subsection{Other Variables}

Participants specified their sex, age, and semester standing (i.e., how many semesters they had been enrolled in university). Furthermore, after completion of the task, participants rated how much fun the symbol task was on rating scales from fun (8) to no fun (0). Using the same scales, participants further rated how much fun they imagined the joke task to be after being introduced to it. Additionally, for those participants who engaged in the joke task, an assessment was made as to how much fun the joke task actually was.

\subsection{Procedure}

Participants were randomly assigned to the four experimental conditions. A trained experimenter conducted all experiment sessions. Depending on their availability, one to three students were assessed at a time; however, room dividers were set up to prevent any interference between participants during testing. At the beginning of the experiment, the experimenter explained the main task to the students. Allegedly, the task was about how easily different symbols could be identified. To create a performance situation, students were told that they would be given 30 minutes to work on the task and that they should try to work as fast, but also as conscientiously, as possible. Additionally, students were given a booklet with 28 jokes and were told that they were allowed to switch to reading and rating one or more of the jokes if they felt like they needed a break. After working on the task for 30 minutes, participants were told to stop and fill out a questionnaire that contained the dependent as well as the other variables. After the experiment was completed, participant received money or course credit for their participation, depending on their choice.

\subsection{Data Analysis}

For the Schwartz scales, the value scores for each person were centered on that person's mean score of all value items, in order to control for differences in scale use and as is advised for correlations and analyses of variance (Schwartz, 1992, 2009; Schwartz et al., 2001). All administered value items (51 altogether) were used to calculate the mean score because centering a reasonably comprehensive set of values is necessary (Schwartz, 2009). Both hypotheses dealt with the influence of the experimental manipulation on a set of values and were analyzed by multivariate analyses of variance with the two dependent variables and the two experimental factors as independent variables. Sex was used as a covariate. The interaction term was tested by using the Pillai trace; a multivariate test calculated based on Eigen values that have been shown to be conservative and robust to violations of assumptions (Olson, 1976). When the interaction term was significant, we then followed up with univariate variance analyses to determine whether the results fit the expectations that the experience of high motivational interference should only decrease conformity and achievement values, and increase hedonistic and well-being values, if self-focus is high.

\section{Results}

\subsection{Preliminary Analyses}

The experimental design was chosen to resemble the situation that many students face when they have to work intently on a task for school while another task that is more fun is available. To test the validity of the setting, students' attractiveness ratings for the main and the alternative tasks were compared. Because not all participants engaged in the alternative task during the experiment, it was important that the fun that students imagined the joke task to be after being introduced to it, as well as the actual fun that the joke task was, was higher than for the symbol task. Indeed, participants imagined the joke task $(M=7.10 ; S D=1.68)$ to be more fun than the symbol task $(M=4.95 ; S D=2.12 ; p<.001 ; d=1.12)$. Also, participants who engaged in the joke task rated the joke task as more fun $(M=7.16 ; S D=1.58)$ than the symbol task $(M=4.69 ; S D=2.00 ; p<.001 ; d=1.37)$.

Throughout the experiment, 46 students took the opportunity to rate jokes. On average, $7.53(S D=9.14)$ jokes were rated. During the allotted 30 minutes, participants completed the search for an average of 14.36 symbols $(S D=3.69)$. As a further measure of achievement that also takes accuracy into account, for each participant the overall number of hits minus the number of false alarms was calculated. Participants achieved an average of 70.24 points ( $S D=21.41$; with a theoretical maximum of 141 points). Independent t-tests showed that neither the fun associated with either task nor the number of jokes rated, nor participants' speed or accuracy in the symbol task, was affected by participants' age, semester standing, or whether they chose money or class credit for their participation. A difference on the average number of completed symbols was found only for sex: On average, female participants $(M=14.85 ; S D=3.66)$ completed more symbols than male participants $(M=12.95 ; S D$ 
$=3.59 ; p=.047 ; d=0.52$ ). Therefore, sex was controlled for when analyzing the hypotheses.

Internal consistencies of the dependent variables are depicted in Table 1. As is often the case with value measures, reliabilities are not very high in terms of traditional cut-offs (Schwartz et al., 2001). However, considering the small number of items that assess conceptually broad definitions, they are quite reasonable (Schwartz, 1992). Table 1 displays inter correlations between the dependent variables.

\section{Insert Table 1 Here}

\subsection{Results for Hypotheses}

Table 2 displays mean values and standard deviations of the four dependent variables separately for the four experimental conditions. The interaction term in the multivariate analysis of variance was statistically significant (Pillai trace $=0.10 ; F=4.11 ; d f=2,73 ; p=.02 ; \eta_{p}{ }^{2}=.10$ ). Univariate analyses showed that the interaction effect was statistically significant for achievement $\left(F=4.92 ; d f=1,74 ; p=.03 ; \eta_{p}{ }^{2}=.06\right)$ and marginally for conformity $(F=3.03 ; d f=1,74 ; p=.09)$. Figure 2 displays the significant interaction effect. In line with expectations, achievement values were higher for the fantasy context than for the no fantasy context condition only when self-focus was high, whereas the reverse pattern holds for the low self-focus condition. Therefore, hypothesis 1 was partly supported.

\section{Insert Table 2 Here}

The interaction term in the multivariate analysis of variance with the two dependent variables (i.e., hedonistic and well-being values) and the two experimental factors as independent variables was not statistically significant (Pillai trace $=0.02 ; F=0.54 ; d f=2,73 ; p=.58$ ). Thus, hypothesis 2 was not supported.

\section{Insert Figure 2 Here}

\section{Discussion}

Results indicated an effect of the experimental manipulation on participants' achievement values. This finding suggests an explanation to previously found cross-sectional correlations between achievement values and the experience of motivational interference (e.g., Fries et al., 2005; Hofer et al., 2007), with an influence of conflict experience on achievement values. Values are often measured using similarity ratings because this method is seen as easier to understand for the participants and less intellectually demanding than abstract importance ratings (Bubeck \& Bilsky, 2004; Schwartz et al., 2001). Possibly, in this format—which requires participants to imagine another person and then compare any peculiarities to their own-inferences about values are especially likely because this leads individuals to take an outside-observer view of themselves. The interpretation that students change their achievement values depending on their experience with achievement-related tasks is in line with the idea that people evaluate those areas of life that are connected with positive experiences as more important. It has been argued that enjoyment of learning enhances interest (Pekrun, Goetz, Titz, \& Perry, 2002). Interest, in turn, is characterized by a high personal significance of the object of interest (Krapp, 2002) The positive correlations between achievement and interest found in meta-analyses are typically explained with a reciprocal influence; that is, prior achievement also influences later interest (Schiefele, Krapp, \& Schreyer, 1993), a predictor that can be seen as related to positive feelings. Indeed, in longitudinal studies, how much students liked school subjects could be predicted with the grades they earned earlier on (Helmke, 1993). And interest in a school subject was related to prior self-concept (Marsh, Trautwein, Lüdtke, Köller, \& Baumert, 2005). Similarly, students have been known to place high subjective task value on domains they are good at (Denissen, Zarrett, \& Eccles, 2007).

Analyses did not show effects of the experimental manipulation on hedonism and well-being values. Results might suggest interpreting previously found cross-sectional correlations of conformity, hedonism, and well-being values with conflict experiences (Fries et al., 2005; Hofer, Kuhnle, Kilian, Marta, \& Fries, 2011) as more of an influence of these values on conflict experiences than vice versa. Especially when taking the results of the present experiment together with the results from Hofer, Kilian, Kuhnle, and Schmid (2011), who found an influence of well-being values on motivational interference, an interesting picture seems to emerge: The previously found cross-sectional correlation between well-being value orientation and motivational interference might be more of an influence of the value on experience. In contrast, the correlation between achievement value orientation and experience in conflict situations emerges as more of an influence of the conflict experience on values.

It might also be possible that the absence of the expected effects for conformity, hedonism, and well-being is found because in the created experimental context, students put their focus more on the performance task while the incentives coming from rating jokes are not distracting enough. Personal values could be affected if 
distractions were more relevant for students' goals, such as when a friend is waiting outside. The results could also be explained in terms of action identification. When people think about what they are doing, they can identify their actions on various levels (Vallacher \& Wegner, 2000). Thus, the main task and alternative task of the experiment can be identified on a rather low level (looking for the next symbol that is a circle with a cross or turning the page and reading the next joke) or on a high level (working as well as possible or having some fun). Personal values are only expected to change based on conflict experiences if the actions in conflict are identified on a high level related to values. Thus, according to our reasoning, it was necessary for participants to identify the main task and the alternative task on a rather high level, and perceive links between those tasks and the respective values. Although people are generally inclined to identify actions on a rather high level, if actions are disrupted by some means, there is a tendency for a lower-level identity to become prepotent (Vallacher \& Wegner, 2000). Thus, being disrupted in the main task by the temptation of the joke task-a condition that was expected to lead to an increase in well-being and hedonistic values - might have actually lowered participants' level of action identification in a way that made value change unlikely.

Future studies should aim at increasing the differences in motivational interference between the experimental groups by not only manipulating the incentive of the main task but also the incentive of the attractive alternative because both determine motivational interference (Fries et al., 2008). Although we attempted to construct an achievement situation by telling students to work as fast and as conscientiously as possible, it could be argued that our task differed from real life achievement tasks of students in two ways: First, in real life, studying is an instrumental means to an end (e.g., a good grade at the end of the year), whereas here, it was only relevant for the experiment. Second, in order to avoid confounding effects of previous knowledge or interest in the task, we chose a rather simple, monotonous task, whereas teachers in real life usually try to make tasks more meaningful. It is unclear as to what extent this influenced students' reactions.

Despite these limitations, the study highlights that, for practitioners, it is important to help students harmonize school and leisure activities and to synthesize the different values associated with them. Negative experiences while performing an achievement-related task when a leisure activity is beckoning can downgrade achievement values. These students might be prone to even more negative experiences while studying later on. The subsequent perception of these negative experiences, in turn, might lead to even lower achievement values, resulting in a downward spiral of the achievement domain. Therefore, for practitioners, it is crucial to reduce school-leisure conflicts early on, for example, by encouraging fixed time slots for school as well as leisure activities in order to increase habitual behavior (Hofer, 2007), or by fostering students' self-determined motivation for school (Ratelle et al., 2005). Furthermore, practitioners should support students in pursuing multiple goals at the same time, by making originally boring achievement tasks more interesting through variation of the task itself, or through working on the task together with others (Sansone \& Thoman, 2006; Sansone, Weir, Harpster, \& Morgan, 1992).

\section{Acknowledgment}

We would like to thank Anastasia Byler for copyediting.

\section{References}

Bardi, A., \& Schwartz, S. H. (2003). Values and behavior: Strength and structure of relations. Personality and Social Psychology Bulletin, 29, 1207-1220. http://dx.doi.org/10.1177/0146167203254602

Bem, D. J. (1967). Self-perception: An alternative interpretation of cognitive dissonance phenomena. Psychological Review, 74, 183-200. http://dx.doi.org/10.1037/h0024835

Bem, D. J. (1972). Self-perception theory. In L. Berkowitz (Ed.), Advances in experimental social psychology (Vol. 6., pp. 1-62). New York: Academic Press.

Bernard, M. M., Maio, G. R., \& Olson, J. M. (2003). Effects of introspection about reasons for values: Extending research on values-as-truisms. Social Cognition, 21, 1-25. http://dx.doi.org/10.1521/soco.21.1.1.21193

Bubeck, M., \& Bilsky, W. (2004). Value structure at an early age. Swiss Journal of Psychology, 63, 31-41. http://dx.doi.org/10.1024/1421-0185.63.1.31

Cordova, D. I., \& Lepper, M. R. (1996). Intrinsic motivation and the process of learning: Beneficial effects of contextualization, personalization, and choice. Journal of Educational Psychology, 88, 715-730. http://dx.doi.org/10.1037/0022-0663.88.4.715

Damrad-Frye, R., \& Laird, J. D. (1989). The experience of boredom: The role of the self-perception of attention. Journal of Personality and Social Psychology, 57, 315-320. http://dx.doi.org/10.1037/0022-3514.57.2.315 
Denissen, J. J., Zarrett, N. R., \& Eccles, J. S. (2007). I like to do it, I'm able, and I know I am: Longitudinal couplings between domain-specific achievement, self-concept, and interest. Child Development, 78, 430-447. http://dx.doi.org/10.1111/j.1467-8624.2007.01007.x

Dietz, F. (2006). Warum Schueler manchmal nicht lernen: Der Einfluss attraktiver Alternativen auf Lernmotivation und Leistung. [Why students sometimes do not study: The influence of attractive alternatives on learning motivation and achievement.] Frankfurt am Main: Peter Lang.

Dolinski, D. (2000). On inferring one's beliefs from one's attempt and consequences for subsequent compliance. Journal of Personality and Social Psychology, 78, 260-272. http://dx.doi.org/10.1037/0022-3514.78.2.260

Duval, S., \& Wicklund, R. A. (1972). A theory of objective self-awareness. New York: Academic Press.

Fenigstein, A., Scheier, M. F., \& Buss, A. H. (1975). Public and private self-consciousness: Assessment and theory. Journal of Consulting and Clinical Psychology, 43, 522-527. http://dx.doi.org/10.1037/h0076760

Fries, S., \& Dietz, F. (2007). Learning in the face of temptation: The case of motivational interference. Journal of Experimental Education, 76, 93-112. http://dx.doi.org/10.3200/JEXE.76.1.93-112

Fries, S., Dietz, F., \& Schmid, S. (2008). Motivational interference in learning: The impact of leisure alternatives on subsequent self-regulation. Contemporary Educational Psychology, 33, 119-133. http://dx.doi.org/10.1016/j.cedpsych.2007.10.001

Fries, S., Schmid, S., Dietz, F., \& Hofer, M. (2005). Conflicting values and their impact on learning. European Journal of Psychology of Education, 20, 259-274. http://dx.doi.org/10.1007/BF03173556

Fries, S., Schmid, S., \& Hofer, M. (2007). On the relationship between value orientation, valences, and academic achievement. European Journal of Psychology of Education, 22, 201-216. http://dx.doi.org/10.1007/BF03173522

Grube, J. W., Mayton, D. M., \& Ball-Rokeach, S. J. (1994). Inducing change in values, attitudes, and behaviors: Belief system theory and the method of value self-confrontation. Journal of Social Issues, 50, 153-173. http://dx.doi.org/10.1111/j.1540-4560.1994.tb01202.x

Helmke, A. (1993). Die Entwicklung der Lernfreude vom Kindergarten bis zur 5. Klassenstufe. [Development of affective attitudes towards learning from kindergarten to grade five.] Zeitschrift für Pädagogische Psychologie, 7, $77-86$.

Hofer, M. (2007). Goal conflicts and self-regulation: A new look at pupils' off-task behavior in the classroom. Educational Research Review, 2, 28-38. http://dx.doi.org/10.1016/j.edurev.2007.02.002

Hofer, M., Kilian, B., Kuhnle, C., \& Schmid, S. (2011). Der Einfluss von Wertorientierungen auf motivationale Interferenz und Lernerfolg. [The influence of value orientations on motivational interference and learning outcome.] Zeitschrift für Pädagogik, 57, 385-403.

Hofer, M., Kuhnle, C., Kilian, B., Marta, E., \& Fries, S. (2011). Motivational interference in school-leisure conflict and learning outcomes: The differential effects of two value conceptions. Learning and Instruction, 21, 301-316. http://dx.doi.org/10.1016/j.learninstruc.2010.02.009

Hofer, M., Reinders, H., \& Fries, S. (2010). Wie sich Werte ändern. Ein zieltheoretischer Vorschlag zur Erklärung individuellen und gesellschaftlichen Wertewandels. [How values change. A goal-theoretic approach to explain individual and societal value change.] Zeitschrift für Entwicklungspsychologie und Pädagogische Psychologie, 42, 26-38. http://dx.doi.org/10.1026/0049-8637/a000003

Hofer, M., Schmid, S., Fries, S., Dietz, F., Clausen, M., \& Reinders, H. (2007). Individual values, motivational conflicts, and learning for school. Learning and Instruction, 17, 17-28. http://dx.doi.org/10.1016/j.learninstruc.2006.11.003

Hofer, M., Schmid, S., Fries, S., Kilian, B., \& Kuhnle, C. (2010). Reciprocal relationships between values and motivational interference during learning and leisure. British Journal of Educational Psychology, 80, 623-645. http://dx.doi.org/10.1348/000709910X492180

Hofmann-Towfigh, N. (2007). Do students' values change in different types of schools? Journal of Moral Education, 36, 453-473. http://dx.doi.org/10.1080/03057240701688010

Inglehart, R. (1997). Modernization and postmodernization: Cultural, economic and political change in 43 societies. Princeton: Princeton University Press. 
Inglehart, R., \& Welzel, C. (2005). Modernization, cultural change, and democracy. New York: Cambridge University Press.

Kilian, B., Hofer, M., \& Kuhnle, C. (2010). Value orientations as determinants and outcomes of conflicts between on-task and off-task actions in the classroom. Learning and Individual Differences, 20, 501-506. http://dx.doi.org/10.1016/j.lindif.2010.03.003

Koriat, A., \& Levy-Sadot, R. (1999). Processes underlying metacognitive judgments: Information-based and experience-based monitoring of one's own knowledge. In S. Chaiken, \& Y. Trope (Eds), Dual-process theories in social psychology (pp. 483-502). New York: Guilford Press.

Krapp, A. (2002). Structural and dynamic aspects of interest development: Theoretical considerations from an ontogenetic perspective. Learning and Instruction, 12, 383-409. http://dx.doi.org/10.1016/S0959-4752(01)00011-1

Marsh, H. W., Trautwein, U., Lüdtke, O., Köller, O., \& Baumert, J. (2005). Academic self-concept, interest, grades, and standardized test scores: Reciprocal effects models of causal ordering. Child Development, 76, 397-416. http://dx.doi.org/10.1111/j.1467-8624.2005.00853.x

Olson, C. L. (1976). On choosing a test statistic in multivariate analyses of variance. Psychological Bulletin, 83, 579-586. http://dx.doi.org/10.1037/0033-2909.83.4.579

Parker, L. E., \& Lepper, M. R. (1992). Effects of fantasy contexts on children's learning and motivation: Making learning more fun. Journal of Personality and Social Psychology, 62, 625-633. http://dx.doi.org/10.1037/0022-3514.62.4.625

Pekrun, R., Goetz, T., Titz, W., \& Perry, R. (2002). Academic emotions in students' self-regulated learning and achievement: A program of qualitative and quantitative research. Educational Psychologist, 37, 91-105. http://dx.doi.org/10.1207/S15326985EP3702_4

Ratelle, C. F., Vallerand, R. J., Senécal, C., \& Provencher, P. (2005). The relationship between school-leisure conflict and educational and mental health indexes: A motivational analysis. Journal of Applied Social Psychology, 35, 1800-1823. http://dx.doi.org/10.1111/j.1559-1816.2005.tb02196.x

Robak, R. W., Ward, A., \& Ostolaza, K. (2006). Development of a general measure of individuals' recognition of their self-perception processes. North American Journal of Psychology, 8, 337-344.

Rokeach, M. (1973). The nature of human values. New York: The Free Press.

Rokeach, M. (1975). Long-term value change initiated by computer feedback. Journal of Personality and Social Psychology, 32, 467-476. http://dx.doi.org/10.1037/h0077077

Rokeach, M. (2003). Long-range experimental modification of values, attitudes, and behavior. In S. Plaus (Ed.), Understanding prejudice and discrimination (pp. 474-480). New York: McCraw Hill.

Rokeach, M., \& Cochrane, R. (1972). Self-confrontation and confrontation with another as determinants of long-term value change. Journal of Applied Social Psychology, 2, 283-292. http://dx.doi.org/10.1111/j.1559-1816.1972.tb01280.x

Sansone, C., \& Thoman, D. B. (2005). Interest as the missing motivator in self-regulation, European Psychologist, 10, 175-186. http://dx.doi.org/10.1027/1016-9040.10.3.175

Sansone, C., \& Thoman, D. B. (2006). Maintaining activity engagement: Individual differences in the process of self-regulating motivation. Journal of Personality, 74, 1697-1720. http://dx.doi.org/10.1111/j.1467-6494.2006.00425.x

Sansone, C., Weir, C., Harpster, L., \& Morgan, C. (1992). Once a boring task always a boring task? Interest as a self-regulatory mechanism. Journal of Personality and Social Psychology, 63, 379-390. http://dx.doi.org/10.1037/0022-3514.63.3.379

Schiefele, U., Krapp, A., \& Schreyer, I. (1993). Metaanalyse des Zusammenhangs von Interesse und schulischer Leistung. [Metaanalysis of the relationship between interest and school achievement.] Zeitschrift für Entwicklungspsychologie und Pädagogische Psychologie, 25, 120-148.

Schmid, S., Hofer, M., Dietz, F., Reinders, H., \& Fries, S. (2005). Value orientations and action conflicts in students' everyday life: An interview study. European Journal of Psychology of Education, 20, 243-257. http://dx.doi.org/10.1007/BF03173555

Schwartz, S. H. (1992). Universals in the content and structure of values: Theoretical advances and empirical 
tests in 20 countries. In M. P. Zanna (Ed.), Advances in Experimental Social Psychology (pp. 1-65). San Diego: Academic Press.

Schwartz, S. H. (1996). Value priorities and behavior: Applying of theory of integrated value systems. In C. Seligman, J. M. Olson, \& M. P. Zanna (Eds.), The psychology of values: The Ontario Symposium (Vol. 8, pp. 1-24). Hillsdale, NJ: Erlbaum.

Schwartz, S. H. (2006). A theory of cultural value orientations: Explication and applications. Comparative Sociology, 5, 137-182. http://dx.doi.org/10.1163/156913306778667357

Schwartz, S. H. (2009). Human values. European Social Survey Education Net. [Online] Available: http://essedunet.nsd.uib.no/cms/topics/1/

Schwartz, S. H., Melech, G., Lehmann, A., Burgess, S., Harris, M., \& Owens, V. (2001). Extending the cross-cultural validity of the theory of basic human values with a different method of measurement. Journal of Cross-Cultural Psychology, 32, 519-542. http://dx.doi.org/10.1177/0022022101032005001

Sheldon, K. M. (2005). Positive value change during college: Normative trends and individual differences. Journal of Research in Personality, 39, 209-223. http://dx.doi.org/10.1016/j.jrp.2004.02.002

Vallacher, R. R., \& Wegner, D. M. (2000). What do people think they are doing? Action identification and human behavior. In E. T. Higgins, \& A. W. Kruglanski (Eds.), Motivational science: Social and personality perspectives (pp. 215-228). New York: Psychology Press.

Verkasalo, M., Goodwin, R., \& Bezmenova, I. (2006). Values following a major terrorist incident: Finnish adolescent and student values before and after September 11, 2001. Journal of Applied Social Psychology, 36, 144-160. http://dx.doi.org/10.1111/j.0021-9029.2006.00007.x

Wang, S.-K., \& Reeves, T. C. (2007). The effects of a web-based learning environment on student motivation in a high school earth science course. Educational Technology Research and Development, 55, 169-192. http://dx.doi.org/10.1007/s11423-006-9016-3

Table 1. Cronbach's $\alpha$ and intercorrelations of dependent variables

\begin{tabular}{|c|c|c|c|c|}
\hline & \multicolumn{4}{|c|}{ Correlations } \\
\hline & Cronbach's $\alpha$ & 1 & 2 & 3 \\
\hline 1. Achievement & .68 & & & \\
\hline 2. Conformity & .70 & .01 & & \\
\hline 3. Well-being & .66 & $-.38 * *$ & $-.50 * *$ & \\
\hline 4. Hedonism & .71 & $-.27^{*}$ & $-.27 *$ & $.60 * *$ \\
\hline
\end{tabular}

$* p<05 . * * p<.01$. 
Table 2. Means and standard deviations on the dependent variables of the four experimental groups

\begin{tabular}{|l|l|l|l|l|l|l|l|l|}
\hline & \multicolumn{2}{|l|}{$\begin{array}{l}\text { Group a: } \\
\text { fantasy context } \\
\text { high self-focus } \\
(n=20)\end{array}$} & \multicolumn{3}{l}{$\begin{array}{l}\text { Group b: } \\
\text { fantasy context } \\
\text { low self-focus } \\
(n=19)\end{array}$} & \multicolumn{2}{l|}{$\begin{array}{l}\text { Group c: } \\
\text { no fantasy context } \\
\text { high self-focus } \\
(n=19)\end{array}$} & \multicolumn{2}{l}{$\begin{array}{l}\text { Group d: } \\
\text { no fantasy context } \\
\text { low self-focus } \\
(n=22)\end{array}$} \\
\cline { 2 - 10 } & $M$ & $S D$ & $M$ & $S D$ & $M$ & $S D$ & $M$ & $S D$ \\
\hline Achievement & 0.37 & 0.66 & 0.07 & 0.59 & 0.14 & 0.57 & 0.41 & 0.52 \\
\hline Conformity & -0.54 & 0.79 & -0.26 & 0.69 & -0.32 & 0.78 & -0.39 & 0.71 \\
\hline Well-being & 0.17 & 0.69 & 0.22 & 0.64 & -0.05 & 0.77 & 0.06 & 0.79 \\
\hline Hedonism & 0.40 & 0.78 & 0.64 & 0.63 & 0.27 & 0.71 & 0.26 & 0.79 \\
\hline
\end{tabular}

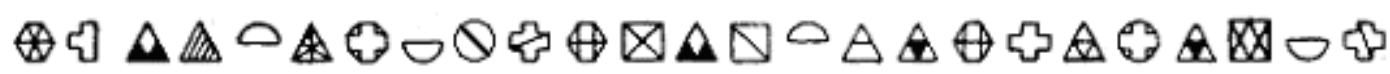

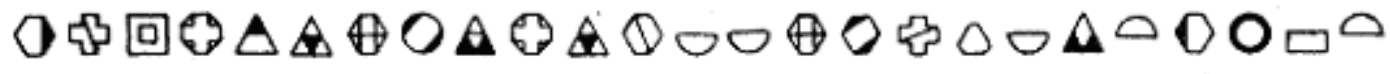

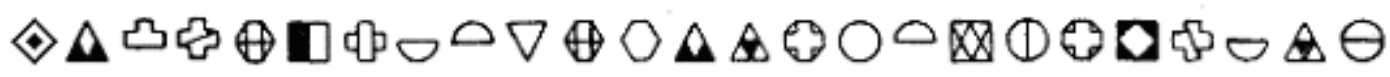
ॠ四 ऊम

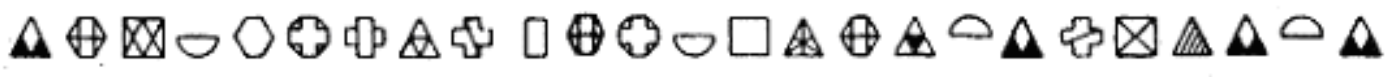

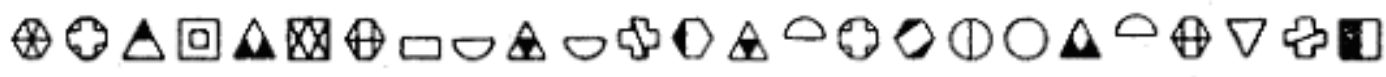

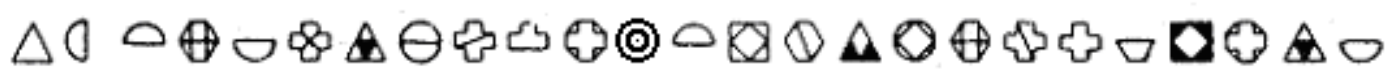

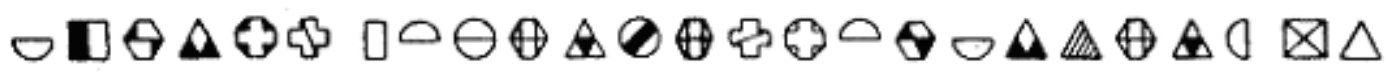

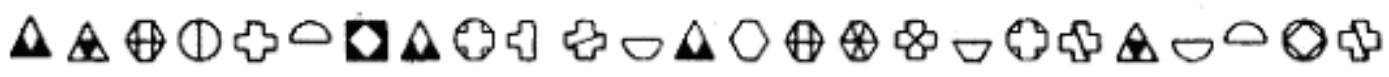

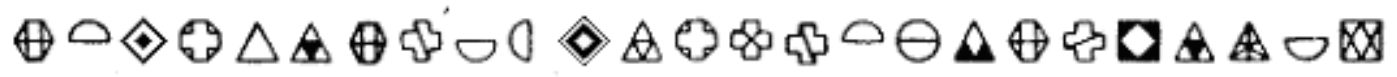

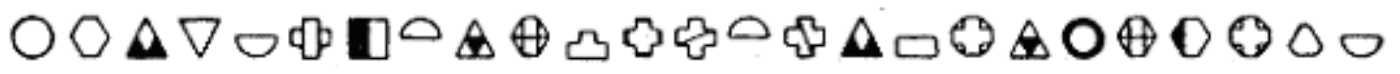

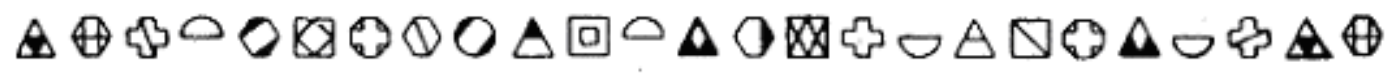

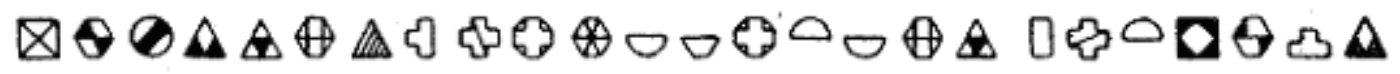

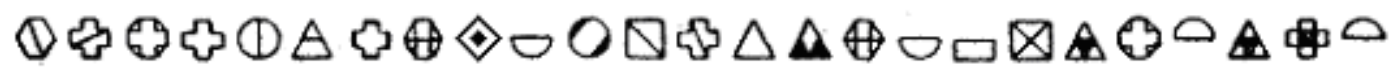

Figure 1. The matrix of symbols for the performance task 


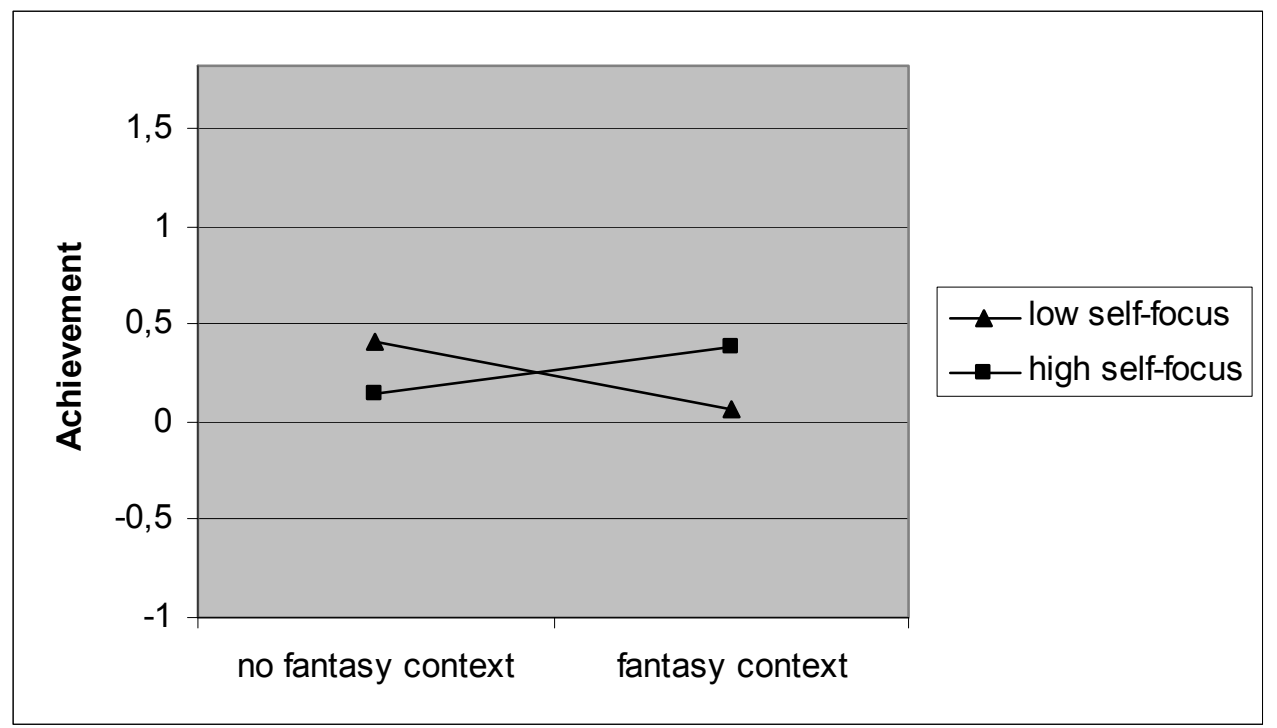

Figure 2. Interaction between fantasy context vs. no fantasy context and low vs. high self-focus in predicting achievement values, Range of achievement values is depicted on y-axis 